\title{
Unconventional foods: salvation or sensuality
}

\author{
By D. S. Miller, Queen Elizabeth College, Campden Hill Road, \\ London $W 8{ }_{7} A H$
}

Some explanation for the title of this paper is necessary. The contention is that unconventional foods are unlikely to make a significant contribution to the world food problem although they may provide sophisticated sensual enjoyment. Eating not only provides nutrients but is also fun, and both are important to man. Those of us who attempt to modify the nutrient content of human diets with a view to improving health know we cannot ignore the pleasures of good food. A food has no nutritional value unless it is eaten. Although starving people may eat because they are hungry, most of us do so because we enjoy eating and nutritional considerations are low on our list of factors influencing food choice. Even starving people have strong food preferences, and have been known to refuse unusual food either because they did not like it or because they lacked the domestic skills to make it palatable. The rejection of maize supplied during the Irish potato famine is one example, which also illustrates the problem of defining the term 'unconventional food'. Clearly what is conventional in one culture could be taboo in another. Maize was an unconventional food to the Irish potato eaters in the nineteenth century, but not to the tortilla eaters of Mexico: it was pellagragenic for the poor whites in America who did not use Mexican traditional methods of preparation: it was also an unconventional food to the English but in the twentieth century it successfully replaced the cooked breakfast in the form of cornflakes. Clearly it is possible to change people's food habits but it requires good technology and careful marketing. It seems evident also that success is more likely in a society with a sophisticated palate that can afford to experiment and that seeks variety in textures, colours and flavours. How else can one explain the serving at American parties of blue cocktails with chocolate-coated ants? Nevertheless, one must recognize that there are some foods that have never been previously consumed by man and which would be unconventional in any culture.

Over 30 years ago our Society held a symposium on this subject (Nutrition Society, 1953) and the topics included seaweeds, mushrooms and insects as well as the indigenous foods of tropical countries and the diets of aboriginals and eskimos. It was one of the first meetings I attended and I can still vividly remember $\mathrm{Dr}$ Bristowe's offer to eat house spiders for cash, and the account of his meeting with His Serene Highness Prince Sithiporn of Siam (sic) who was fond of the roasted larvae of the coffee-boring moth which in his view were clean-feeding caterpillars compared with such scavengers as lobsters or shrimps: the prince expressed disgust at our consumption of 'high' game and decaying cheese. Dr Bristowe's enthusiasm for spiders extended to the blue-legged mygalomorph which achieves $60 \mathrm{~mm}$ in length and $4 \circ \mathrm{g}$ in weight but I have heard no reports of their being eaten 
outside Thailand. Those who wish to sample the delights of cicadas, termites or giant water bugs will find them on sale currently at the Sunday market in Bangkok: also locusts and grasshoppers are seasonally available food in the Near East and Africa. Snails must be regarded as unconventional in Britain if not in France, although snail farms do exist in Somerset: in Ghana the price of the giant African snail is sufficiently important to be quoted in the daily newspapers. Similarly, squid is commonplace in Europe although it is rarely eaten alive as in Korea where its suckers may stick to the roof of the mouth of the uninitiated. Reptiles, snakes and lizards are only eaten by eccentrics in the West but are a common sight in the shops in the Far East where they are sold not only as food but also as aphrodisiacs.

Indeed, none of the foods I have mentioned so far substantially contribute to the nutrients of the diets of those who consume them. They are eaten mainly because they are enjoyed in their own right but also because they enable the consumption of a bland bulky diet which would be awfully dull without them. Many may be regarded as luxury foods, the poor having to use cheap spices to make the starchy main dish more palatable. Nevertheless, one should not ignore this important role of such special foods because they can regulate energy intake. In Ethiopia food intakes are extremely low and yet one may observe people leaving food on the table simply because there was not sufficient side-dish to help the staple down: when more meat is available energy intakes rise.

\section{The protein gap}

The sensory qualities of food were almost completely overlooked by the enthusiastic natural scientists who were attempting to overcome what was thought to be a world shortage of protein. The story properly begins during World War II when the authorities were worried about protein deficiency amongst some groups of the population: they were using the high values for protein requirements given by authorities such as the old League of Nations. Some effort was put into producing protein from unusual sources and a banquet was given for the Minister of Food, Lord Woolton, to establish the palatability of some of the products, e.g. whale steaks and green cheese made from leaf protein. However, the gastronomic standards in wartime were austere and it is clear that such an exercise would be a disaster today. There was also concern about lack of protein in food because of its physical properties, e.g. the shortage of eggs made it extremely difficult to bake cakes and some enthusiasts attempted to make substitutes such as fish albumin from fish-house waste. After the war there were a number of books from neo-Malthusians who were concerned with population outstripping food supply and attention switched slowly from the nutritional problems of Europe to those of developing countries. Many of these pessimists thought that the production of staple foods was much less of a problem than the supply of protein-rich foods, and it is of interest that their successors now take exactly the opposite view.

Thus, for the period 1950-70, science and technology pressed governments and the international agencies to finance the production of protein-rich foods for the 
Third World whose peoples neither needed them nor enjoyed them, and who certainly could not afford to buy them. To be fair to our profession, there was extensive malnutrition in the Third World and a genuine liberal concern to do something about it: also there were surpluses of skimmed milk and a depressed market in oil-seed residues, such that there was commercial interest in the exercise. Finally the philosophy of the age was that technology could solve any problem: had not vitamin and mineral supplementation of foods been highly successful in preventing deficiency diseases? It was felt that the production of protein of high biological value was the magic solution to the present difficulties and what is more it could provide business for the factories of the West. There followed a spate of foods from unconventional sources: apart from leaf protein there were flours made from soya bean, cottonseed, yeast, groundnut, fish, and micro-organisms grown on oil, gas and alcohol. Coprophagy was not proposed but protein from Esherichia coli was! Most were promoted as odourless, colourless, tasteless, amorphous products which no one knew quite what to do with and certainly no one wanted to eat. It did not seem to occur to anyone that consumer preferences should be taken into account. The strangest case was of the production by an expensive process of deodourized fish meal in Chile, a country that is all coastline, for the nourishment of a population which not surprisingly preferred its fish to taste of fish: when fish meals were submitted to African taste panels there was a marked preference for the stronger flavours.

The international agencies, particularly UNICEF, were keen on making weaning foods and were encouraging some of us to devise appropriate biological tests: the results showed not all were of high biological value and many were damaged by overheating during processing. Eventually some infant foods were produced and used on a limited scale: the most famous, Incaparina in Central America, was oversold to the scientific community but actual sales were limited largely because of price. It was initially marketed by amateurs and only became commercially successful when taken over by a multinational company. There were many imitators: fafa in Ethiopia found a market amongst the middle classes in Addis Ababa but did not penetrate to the poor rural areas. Indeed, our own project in the Simien taught us that cheap weaning foods could be prepared from locally-grown produce.

One day someone will cost the massive investment incurred by the scientific community, the international agencies, governments and commercial enterprise that went into this whole pointless exercise: it must run into billions of dollars! But quite suddenly the enthusiasm waned, and for this there were essentially two reasons. Firstly, the exercise had stimulated a lot of work on protein metabolism and there was growing agreement that protein requirements were set too high: in particular, the low amino acid requirements of man were now confirmed by similar values for women and children. Briefly, the Food and Agriculture Organization and the World Health Organization removed the protein gap not by producing more but by lowering requirements: let no one underestimate the impact of nutritionists sitting in camera on commercial activity in the world! However, let there also be no 
misunderstanding, there is a world shortage of meat, dairy products and eggs in the sense that people would buy more if they could afford to: the demand is not for protein but for attractive foods of high sensual quality. The second reason for the collapse was the first oil crisis of 1973: no longer did we live in a world of unlimited cheap energy and food technologists were forced to do agonizing costings. The Third World might indeed be a vast market but only the well-to-do could afford to buy imported 'high-tech' products: the peasants would have to manage with the proteins they were growing for themselves.

\section{The food gap}

From 1970 to the present day the cry of the neo-Malthusians has been one of population pressure and impending starvation and famine: we are to believe that there is a food crisis as well as an oil crisis. The beginning of the decade was marked by sporadic famines particularly in Africa and food shortages in India and South-east Asia: emergency meetings were held in Rome and the international community was concerned about the political implications of so clear a demonstration of the unequal distribution of the world's resources. Had the much praised 'Green Revolution' which had produced the new high-yielding crop varieties failed? It was at least realized that no 'supra-technology' could deal with the problem, if only because the sheer bulk of food needed could not possibly be produced industrially: factories cannot compete with photosynthesis! It seemed also that the new agricultural techniques benefited the rich landowners but not the subsistence farmers and certainly not the landless nor those in the urban slums. The situation looked bleak indeed, but strangely this problem went away also.

To understand what happened one must ask the right questions. Famine is not a supply problem, it is a demand problem: people starve because they do not have the money to buy food. There is always enough, at least somewhere in the world, and usually locally. In the infamous Ethiopian famine, crop yields for the whole country were average and shortages were limited to one or two provinces. Table I shows that world primary food production provides $19 \mathrm{MJ}\left(45^{1} 4 \mathrm{kcal}\right) /$ head per $\mathrm{d}$ and Table 2 that average food consumption is $10.7 \mathrm{MJ}\left(25^{6} 3 \mathrm{kcal}\right) /$ head per $\mathrm{d}$. These values have remained very stable for at least one generation despite the increase in population. Since average energy requirements are about $8.4 \mathrm{MJ}(2000$ $\mathrm{kcal}) /$ head per $\mathrm{d}$ for man, woman and child, it is clear that there is more than enough for everyone. If people starve it is because of inequitable distribution due to varied economic power: indeed there is an excellent correlation internationally between food intake and gross national product. Whenever there are horrendous pictures on the television screens of malnourished children it is because of economic, political or military reasons. Talk of drought, pestilence, plague, crop failure and population pressure is to talk of soluble problems in a modern world. Farmers can already produce virtually unlimited bounty provided we, the consumers, are prepared to pay them to do so: they are the salt of the earth, somewhat conservative, perhaps unwilling to take risks, but always hardworking and innovative when given guaranteed prices, and certainly capable of feeding the 
Table $\mathrm{I}$. World primary food production (after Miller $1 \mathrm{9} 8 \mathrm{I})^{\bullet}$

\begin{tabular}{|c|c|c|c|c|c|}
\hline & $\begin{array}{l}\mathrm{J} / \text { year } \\
\times 10^{18}\end{array}$ & $\begin{array}{c}\mathrm{cal} / \text { year } \\
\times 10^{18}\end{array}$ & $\begin{array}{l}\mathrm{kJ} / \mathrm{head} \\
\text { perd }\end{array}$ & $\begin{array}{l}\text { kcal/head } \\
\text { per d }\end{array}$ & $\%$ total \\
\hline Wheat & 519 & I 24 & $355^{2}$ & 849 & 19 \\
\hline Rice & 473 & I 13 & $3^{2} 3^{8}$ & 774 & 17 \\
\hline Maize & 460 & I 10 & 3155 & 754 & 17 \\
\hline Barley & $2 \cdot 43$ & $0.5^{8}$ & 1661 & 397 & 9 \\
\hline Potato & 0.96 & 023 & 661 & $15^{8}$ & 4 \\
\hline Soya & 0.96 & 0.23 & $66 \mathrm{I}$ & 158 & 4 \\
\hline Cottonseed oil & 0.96 & 0.23 & $66 t$ & 158 & 4 \\
\hline Cane sugar & 0.84 & $0 \cdot 20$ & 573 & 137 & 3 \\
\hline Oats & 0.80 & O. I 9 & 544 & 130 & 3 \\
\hline Sorghum & 0.75 & 0.18 & 515 & 123 & 3 \\
\hline Millets & 0.67 & 0.16 & 460 & 110 & 2 \\
\hline Sweet potato & 0.63 & 0.15 & $43^{I}$ & 103 & 2 \\
\hline Cassava & 0.63 & 0.15 & $43 \mathrm{I}$ & 103 & 2 \\
\hline Beet sugar & 0.50 & 0.12 & 343 & 82 & 2 \\
\hline Peanuts & 0.50 & 0.12 & 343 & 82 & 2 \\
\hline Rye & 0.46 & $O \cdot I I$ & 314 & 75 & 2 \\
\hline Coconut & 0.46 & 0.11 & 314 & 75 & 2 \\
\hline Grain legumes & 0.29 & 0.07 & 201 & $4^{8}$ & 1 \\
\hline Sunflower seed & 0.21 & 0.05 & 142 & 34 & I \\
\hline Grapes & 0.21 & 0.05 & 142 & 34 & 1 \\
\hline Banana & 0.17 & 0.04 & 113 & 27 & I \\
\hline Oranges & 0.08 & 0.02 & 59 & 14 & \\
\hline Yam & 0.08 & 0.02 & 59 & 14 & \\
\hline Miscellaneous & 0.17 & 0.04 & 113 & 27 & 1 \\
\hline Fish & 0.29 & 0.07 & 201 & $4^{8}$ & I \\
\hline Total & $27 \cdot 5$ & $6 \cdot 59$ & 18887 & $45^{14}$ & 100 \\
\hline
\end{tabular}

-The crops included are those used for human consumption, but about half the yield is used for feeding farm animals.

world when given the right incentives. For those who are still convinced by the prophets of doom, may I recommend a book by J. L. Simon (1981) which I regard as one of the most important of the century: it will not be widely read because it is not scaremongering, but it does provide a sane, well-documented case to counter the belief that man is using up limited resources. It is refreshingly optimistic and sees no limit to the size of population that could be supported on earth: indeed man is 'The Ultimate Resource' of its title.

\section{Food for a sophisticated palate}

I apologize if my maverick paper in this symposium has so far been iconoclastic, but in truth I am all in favour of unconventional foods. To me they offer the possibility firstly of new textures and flavours, and secondly of providing a vehicle for improving the composition of the diet. Sadly these objectives have not been taken up by the marketing men who think entirely of cheap food: they do not seem to value their own products. New sources are often directed 'down market' as cheap meat substitutes, or to the Third World or even for animal feed. There 
Table 2. World food consumption (after Miller $198 \mathrm{1}$ )*

\begin{tabular}{|c|c|c|c|}
\hline & $\begin{array}{l}\mathrm{kJ} / \text { head } \\
\text { per d }\end{array}$ & $\begin{array}{l}\mathrm{kcal} / \mathrm{head} \\
\text { per d }\end{array}$ & $c_{1}$ total \\
\hline Rice & 2121 & 507 & 20 \\
\hline Wheat & 1904 & 455 & 18 \\
\hline Sugar & 1000 & 239 & 9 \\
\hline Meat & 816 & I 95 & 8 \\
\hline Roots and tubers & 732 & 175 & 7 \\
\hline Vegetable oils & 607 & 145 & 6 \\
\hline Maize & 594 & 142 & 6 \\
\hline Milk & 506 & $12 \mathrm{I}$ & 5 \\
\hline Millets and sorghum & 452 & 108 & 4 \\
\hline Animal fats & 322 & 77 & 3 \\
\hline Pulses & 293 & 70 & 3 \\
\hline Alcohol & 259 & 62 & 2 \\
\hline Fruit & 243 & $5^{8}$ & 2 \\
\hline Nuts and oilseeds & 218 & $5^{2}$ & 2 \\
\hline Vegetables & 167 & 40 & 2 \\
\hline Fish & 109 & 26 & I \\
\hline Eggs & 88 & 21 & I \\
\hline Miscellaneous & 293 & 70 & 3 \\
\hline Total & 10724 & 2563 & 100 \\
\hline
\end{tabular}

\footnotetext{
-The figures are derived from food balance sheets, and hence strictly refer to food moving into consumption.
}

seems no desire to promote them as new foods in their own right with their own distinctive texture and flavour. Most people in Britain will have eaten textured vegetable protein but few will know soya-bean curd as prepared by the Chinese from the same source. The second possibility is the design of entirely-new, highly-palatable dishes with a composition close to that recommended by the Health Education Council, i.e. with less fat, sugar and salt but with more dietary fibre. One approach, by the Lord Rank Research Laboratories, is the use of a mycoprotein with remarkable textural properties which makes it an ideal product for the wizardry of food technology: it is bland and can be flavoured as desired, but better sweeteners and salt substitutes than are currently available will have to be found and it will be difficult to retain palatability without added fat. The western palate is habituated to fat and sugar, which provide energy density and facilitate overeating. The biggest challenge is to produce palatable dishes which are bulky and of low energy value: I guess the ultimate objective would be energy-free foods for the obese. Some commercial men doubt the viability of mass marketing foods for health (not to be confused with health foods!) and point to the success of the 'naughty but nice' advertisements. However, in recent years, we have seen a remarkable vogue for the consumption of dietary fibre, supported by a whole new range of fibre-rich products, e.g. white bread with enough added fibre to equal that of brown. The public are becoming more diet conscious and unconventional foods will undoubtedly play their part in the future. 
But for the present it is unconventional foods from exotic cultures that really present gastronomic delight. J. B. S. Haldane claimed that there were three centres of the culinary art, France, China and Southern India: the British cuisine is good but not really in the same class. One of the hazards of our profession is that we are obliged to eat strange foods from other cultures but more often than not the experience is rewarding. In recent years many of these cultures have come to Britain and judging by the spate of ethnic restaurants in our cities it is clear that at least some sophisticated gastronomes are enjoying the products. Often the dishes are made from familiar food cooked differently, but there are also foods from unconventional sources, e.g. sharkfin soup, bamboo shoots, sprouted grain legumes, etc. These immigrant cooks have clearly enhanced our culture, and one hopes that more tropical foods will be introduced into Britain. (Note, this recommendation does not apply to the durian fruit which tastes delicious but stinks unsociably!) It should be noted also that this process is two-way and many European foods are commonplace in developing countries, e.g. wheaten bread, barley beer, Italian pasta, fizzy drinks, etc. Note that it is precisely those foods that are widely consumed here that have been successful abroad. It is a highly dubious procedure to try to sell to the Third World materials we would not consume ourselves, e.g. surplus by-products; such promotions in the past created suspicion and deserved to fail. New foods are for sophisticated palates, first to approve and then to act as trend-setters. Only when the foods have been established as highly desirable are they ready for export. Better by far that they bring sensual delight to jaded palates at home than pretend that they can provide salvation for a hungry world.

The author wishes to acknowledge grants that enabled him to participate in work which was intended to alleviate world food problems but was later found to have been misconceived. The events reported are largely autobiographical.

\section{REFERENCES}

Miller, D. S. (1981). In Food Chains in Human Nutrition, pp. 23-45 [K. Blaxter, editor]. Barking: Applied Science Publishers.

Nutrition Society (1953). Proceedings of the Nutrition Society 12, 32-82.

Simon, J. L. (1981). The Ultimate Resource. New Jersey: Princeton University Press. 